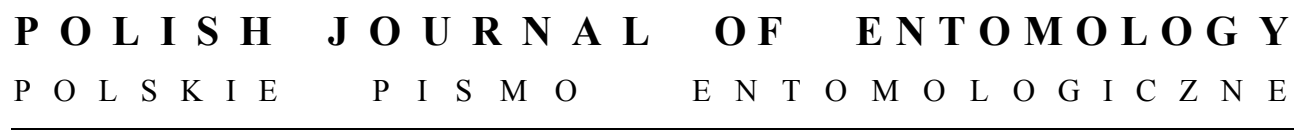

VOL. 81: $347-363$

Gdańsk

31 December 2012

DOI: $10.2478 / \mathrm{v} 10200-012-0015-\mathrm{x}$

\title{
Taxonomy and pollination ecology of Bombus rufofasciatus (Hymenoptera: Apidae) from the Indian Himalaya
}

\author{
MALKIAT S. SAINI ${ }^{1}$, RIFAT H. RAINA ${ }^{1 *}$, ZAKIR H. KHAN ${ }^{2}$ \\ ${ }^{1}$ Department of Zoology Punjabi University Patiala, India, \\ ${ }^{2}$ Division of Entomology SKUAST-K Shalimar Srinagar (J\&K) - India, \\ ${ }^{1 *}$ e-mail: rifat72001@yahoo.co.in
}

\begin{abstract}
Bombus rufofasciatus SMITH is a Tibetan species, widely distributed in the Oriental region. It is a medium tongued species abundant in both the north-east and north-west Indian Himalaya, covering an altitude range from 2400 to $4200 \mathrm{~m}$. Because of its abundance and very wide distribution, it is associated with a sizeable number of host plants. Males and workers are similar in colour pattern, but the queen is a little different. The species shows a preference for highaltitude mountain slopes and is found in abundance in the open meadows of Affarwatt, Sheeshnag, Daksum, the Razdan Pass and the Lahul-spiti Valley of Himachal Pradesh in the north-western Himalaya. For preference it forages on Aconitum spp. (Ranunculaceae), Trifolium spp. (Papilionaceae), Cirsium spp. (Asteraceae) and certain members of Lamiaceae. Due emphasis has been laid on its detailed taxonomic descriptions, synonymy, host plants, pollination ecology, distribution pattern and illustrations. 51 food plants of this species have been recorded for the first time from the areas under study.
\end{abstract}

KEY WORDS: taxonomy, ecology, Bombus rufofasciatus, Indian Himalaya.

\section{INTRODUCTION}

In India, bumble bees are mostly confined to high-altitude regions. Different species are restricted to different altitudinal strata, ranging from $1000 \mathrm{~m}$ to $5500 \mathrm{~m}$. They nest either in the ground, often in abandoned rodent burrows, or above ground in tall grasses (KEARNS \& THOMSON 2001). Recent studies have shown that bumble bees routinely forage at considerable distances from their nests (DRAMSTAD 1996, OSBORNE et al. 1999). They are intimately associated with different types of flowers (wild and cultivated) and are found 
foraging everywhere in different mountain regions. Each species has its own preference for particular flowers to obtain pollen and nectar. These insects prefer open sunny meadows to dense, close-canopied forests. The species confined to very high altitudes are comparatively small in size, dull in colour and produce a high buzzing sound while on the wing. The small size of high-altitude species is directly correlated with the type of vegetation growing in these areas, which generally takes the form of small bushes with very small flowers that need smaller insects for pollination. These economically important insects are responsible for pollinating a wide variety of plants, which in addition to providing food, play a key role in the functioning of agricultural ecosystems. These bees are polylectic, foraging from a wide variety of flowers, and are better suited to survive in human-dominated landscapes than oligolectic, or specialist bees (WESTRICH 1996).

As far as ecological and behavioural studies are concerned, hardly any work has been done on Indian bumble bees. In spite of the fact that bumble bee diversity can be exploited for the pollination of crops, fruit trees, vegetables and medicinal plants, as well as in greenhouse farming and floriculture, nobody has done any work in this respect. The present paper gives the food preferences, detailed taxonomic descriptions, synonymy, illustrations, foraging range, colony size, visiting timings and ecological distribution patterns of Bombus rufofasciatus, which is prevalent in various parts of the north-west Himalayan belt. A separate list of its food plants is provided.

\section{Acknowledgements}

The authors are grateful to ICAR, Govt. of India, New Delhi, for providing financial assistance. We express our gratitude to Dr Paul H. Williams of the Natural History Museum, London, for providing sorely needed literature and for confirming species identifications. Thanks are also due to the Director of BSI, Gangtok, to FRI Dehradun, to Dr Anzar Ahmad Khuroo, Assistant Professor, and to Dr Akhter H. Malik, Curator of the Centre of Plant Taxonomy, University of Kashmir, for identifying the plant species. Special thanks are also due to Mr Mudasir Jeelani and Dr Reyaz Ahmad of the Department of Botany, Punjabi University, Patiala, for confirming the identification of some important plant species.

\section{MATERIALS AND METHODS}

The research material relevant to the present studies consists of some 328 adult specimens of all castes (queens, workers and males) belonging to Bombus rufofasciatus. The material was collected during four years (2006-2010) from various localities in the State of Jammu and Kashmir and Himachal Pradesh at altitudes from 1000 to $5500 \mathrm{~m}$. These localities were systematically surveyed, twice or three times every year (May to July 
for queens and August to October for workers and males). Particular attention was paid to the areas above $2000 \mathrm{~m}$. The altitude of each site was measured with a digital altimeter. Sampling was conducted at sites dominated by the most representative vegetation types of the region (Figs 28-29).

Bumble bees were collected by sweeping with a hand net and later killed with ethyl acetate. Some insects were also collected with a malaise trap. In addition to collection, live photography of the species under study was done with an Olympus camera equipped with different macro lenses.

The collected insect material was first sorted in the field and later brought to the laboratory for further identification and analysis. For the collection of these insects, special transparent killing jars were designed so as to preserve the colour of the pubescence. A paste of plaster of Paris was poured into 10 inch long transparent glass jars and allowed to dry. The solid POP was soaked with ethyl acetate. After placing a cotton wool plug at the top of the POP it was covered with a layer of thick blotting sheet to prevent direct contact between the insect and the ethyl acetate soaked POP. The inner sides of the killing jar were also covered with filter paper to absorb the water vapour that would otherwise spoil the insect's pubescence. As the colour of the pubescence in bumble bees is of great importance in species identification, the necessary care was taken during collection. In view of the delicacy and beauty of the pubescence, insects killed in the killing jar were continuously shifted to another jar of the same size. Each bumblebee was pinned with entomological pins of a size appropriate to that of the insect. After stretching, a label was attached to the specimens containing information on the locality, altitude and date of collection and the name of the collector. Later, the stretched specimens were transferred to storage boxes, poisoned with ethyl-acetate soaked cotton wool and with naphthalene powder filling the side grooves of the boxes. All the identified specimens have been deposited at the Department of Zoology, Punjabi University, Patiala, for future reference.

Temporary slides of different parts, such as the male genitalia, labrum, pollen collecting apparatus, antenna, meso- and meta-basitarsal segments, were prepared in glycerine and alcohol. The genitalia could easily be extracted from fresh specimens with fine forceps, whereas in dried materials the body had to be relaxed overnight in distilled water until it became pliable, after which the genitalia were removed with forceps and placed in $70 \%$ alcohol for further study. Some of their important features, like the penis valve, gonostylus, gonocoxites, gonobase, volsella and spatha are of great taxonomic significance.

The various morphological features were examined under a binocular microscope fitted with an ocular grid. Photographs of the specimens were taken with a Canon 18 MP EOS 5D. During the field survey photographs of live bumble bees along with their host plants were taken with an Olympus Zoom Digital camera (7.2 MP, C A Media C-7070). The species' food preferences were also studied. All the food plants of this species were 
collected; they were identified at the Centre of Plant Taxonomy, University of Kashmir, and confirmation of these identities was obtained from FRI Dehradun.

Colony size, foraging range and visit timings of Bombus rufofasciatus were recorded for which the direct observation and marking method (DRAMSTAD 1996) was followed from time to time at different altitudes in the Himalaya during 2007-2010.

\section{DESCRIPTION}

\section{Bombus (Melanobombus) rufofasciatus SMITH, 1852}

B. rufofasciatus SMITH, 1852: 48, Lectotype queen, India: North (BMNH).

DALla TORRE 1896: 544; SKORIKOV 1923: 160; TKALCU 1974a: 340; WANG 1982: 438, 1988: 556, 1992: 1427; WILLIAMS 1991: 105; WILLIAMS and CAMERON 1993: 127; BURGER et al. 2009: 461.

\section{Synonymy}

B. prshewalskyi MORAWITZ, 1880: 342; B. rufocinctus MORAWITZ, 1880: 343; B. chinensis DAlla TORRE, 1890: 139; B. przewalskyi MORAWITZ, 1890: 349; B. (Lapidariobombus) rufofasciatus var. championi RICHARDS, 1928a: 107; $B$. (Lapidariobombus) rufofasciatus var. rufior RICHARDS, 1928b: 335; B. (Lapidariobombus) rufofasciaitus var. intermedius RICHARDS，1930: 643; B. (Lapidariobombus) waterstoni RICHARDS, 1934: 88; Kozlovibombus przewalskii SKORIKOV, 1923: 152.

\section{Description}

Female (Figs 1, 2). Pubescence on head, mesonotum and abdominal tergum 2 black; pronotum, metanotum and abdominal tergum 1 white; tergum 3 entirely reddish; tergites 4 and 5 white. Workers with abdominal tergum 2 yellow, 3-4 reddish and tergum 5 white; wings light brown. Boss on abdominal tergum 6 nearly circular and evenly convex, only narrowly pointed adjacent to apex of tergum; mid basitarsus, with the distal posterior corner forming nearly a right angle and not sharply pointed; Labrum with basal transverse depression extending apically as a deep median furrow between pronounced lateral tubercles, displacing ridge between them to form a lamella that overhangs apical margin (Fig. 16). Antennal segments 3:4:5=1:5:6.5; LF: LS: LHB=11:5:11.2 (Fig. 14). The distoposterior corner of mesobasitarsus bluntly pointed. Length of disto-posterior corner is less than that of distoanterior corner (Fig. 17). Hind basitarsus with dense pubescence of proximal margin (auricle) continuing onto the outer surface of proximo-posterior projection as just a few sparse hairs, length of projection is equal to its breadth at its base; distal half of its posterior margin weakly concave with distoposterior corner roundly 
pointed and equal to distoanterior corner (Fig. 15); hind basitarsus with the posterior margin nearly straight; the longest of the erect hairs near the anterior margin of the outer surface as long as the greatest breadth of the basitarsus; mandible distally broadly rounded with three teeth; oculo-malar distance approximately 1.1 times the proximal breadth of the mandible; dorsum of the head with large and small punctures scattered almost throughout, except in the ocellar depressions; apex of tergite 7 with a boss nearly circular and evenly convex.

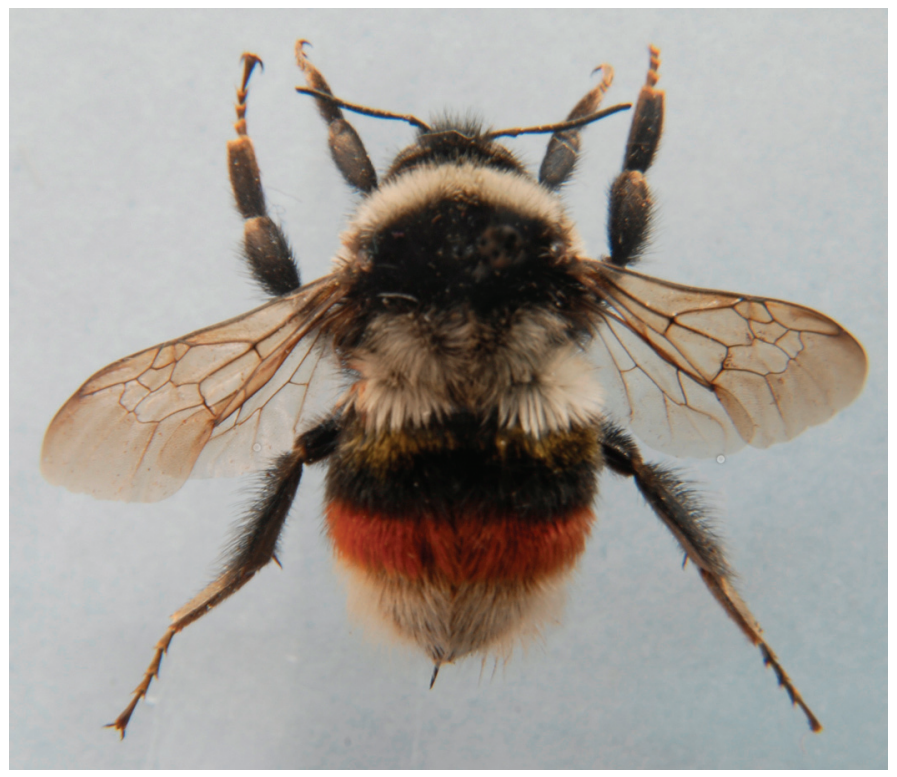

Fig. 1. B. rufofasciatus (queen).

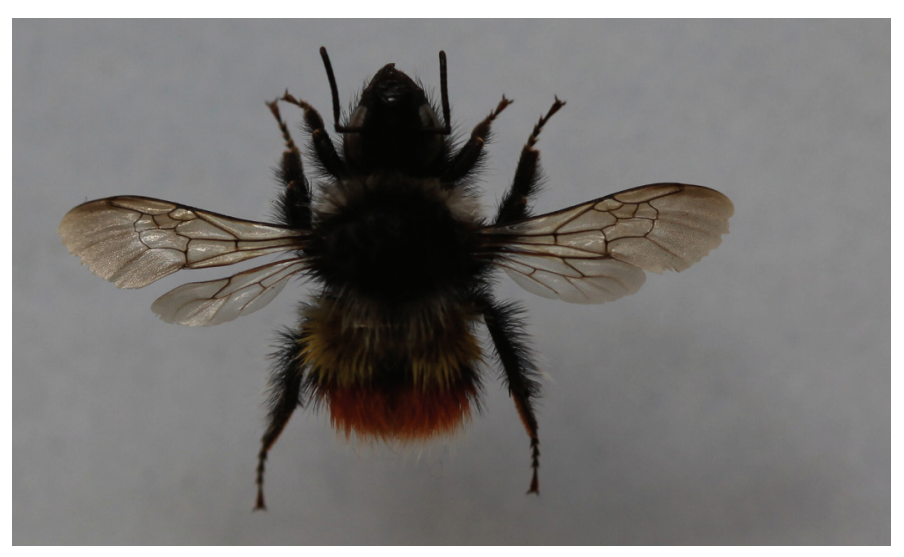

Fig. 2. B. rufofasciatus (worker). 
Male (Fig. 3). Coloration like that of workers. Compound eyes strongly enlarged as compared to the female; antenna reaching posteriorly only just to the wing bases; mandible distally pointed, with one additional tooth (Fig. 21); anterior margin of labrum almost truncate (Fig. 20). Lateral tubercles not meeting in the centre, interrupted by a shallow depression. Except for the tubercles, the rest of the area densely punctured. Antennal segments $\quad 3: 4: 5=1.25: 1: 1.25 ; \quad$ LF:LS:LHB=11:4:10.5 (Fig. 18); MS:BMB=1:1.5; MBB:LOB=3:12.5. Genitalia with the penis valve distally incurved into a sickle shaped head, the recurved crook of the head longer than its proximal breadth, narrowed and straight and the ventro-lateral angle of the penis valve reduced and almost absent; gonostylus distally reduced to an inner bifid process, without an inner submarginal longitudinal groove, the inner proximal process broad and pointed; interio-basal process of gonostylus with apex forming nearly a right angle, interio-apical process with sides diverging towards apex (Figs 9-13).

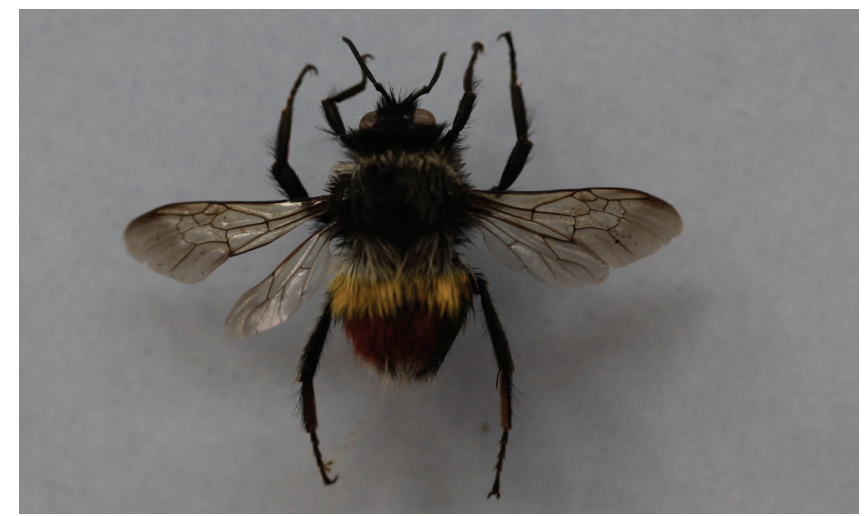

Fig. 3. B. rufofasciatus (male).

\section{Material examined}

Jammu and Kashmir: Baramulla: Affarwatt, 4000 m, 5 females (q), 18 females, 9 males, 21 VIII 2009; Drang, 2400 m, 2 males, 3 IX 2008; Gulmarg, 3000 m, 1 female (q), 5 males, 10 VI 2007, 2 IX 2008; Khilanmarg, 3000 m, 7 females (q), 12 females, 4 males, 10 VI 2007, 2 IX 2008; Anantnag: Aru, 2950 m, 2 females (q), 3 females, 2 males, 8 VIII 2007; Baisaran, 2533 m, 5 males, 29 VIII 2008; Chandanwari, 3000 m, 1 female (q), 8 females, 16 males, 1 IX 2008, 15 VIII 2010; Daksum, 2600 m, 1 female (q), 15 VI 2007; Lidder watt, 3200 m; 6 males, 14 VIII 2008; Mahagunus Top, 4200 m, 6 males, 19 VIII 2010; Pahalgam, 2700 m, 7 males, 30 VIII 2008, 31 VIII 2008; Pishugati, 3300 m, 1 female (q), 8 males, 1 IX 2008, 16 VIII 2010; Sheeshnag, 3500 m, 1 female, 7 males, 26 VIII 
2010; Bandipora: Bagtore, 2467 m, 2 males, 06 IX 2010; Dawar, 2434 m; 2 females (q), 9 females, 13 males, 8 VII 2008, 28 VI 2009; Gosianala, 3000 m, 5 males, 8 IX 2010; Gujran, 3001 m, 1 male, 06 IX 2010; Izmarg, 2500 m, 5 females (q), 3 females, 3 males, 27 VI 2007, 7 IX 2010; Kutroach, 2800 m, 4 females (q), 4 males, 28 VI 2009; Razdhan Pass, 3500 m, 1 female (q), 4 females, 4 males, 8 IX 2010; Ganderbal: Baltal, 3385 m, 1 female, 6 males, 14 VII 2008, 5 VII 2010; Thajiwas, 3100 m, 1 female (q), 22 females, 9 males, 10 VI 2007, 3 IX 2008, 04 VII 2010; Budgam: Doodpather, 2870 m, 1 female (q), 9 females, 4 VI 2007, 20 VI 2010; Yousmarg, 2600 m, 4 females (q), 2 females, 19 VI 2007, 19 VI 2010; Kargil: Drass, 3265 m, 8 females, 7 males, 24 VII 2007, 10 VIII 2008. Himachal Pradesh: Lahaul-Spiti: Koksar, 3200 m, 18 females, 5 VIII 2006, Chotta dara, 4000 m, 13 females, 15 VIII 2006; Chattru, 4000 m, 18 females, 15 VIII 2006 (collection Rifat H. Raina).

\section{Global distribution}

India, Pakistan, Nepal, Bhutan, Myanmar and Tibetan plateau and south-western China (WILLIAMS 2004).

\section{Distribution within India}

Kashmir, Himachal Pradesh, Uttarakhand, Sikkim and Arunachal Pradesh (WILLIAMS 1991, 2004, SAINI et al. 2011, 2012).

Population variation (Figs 4-6)

Some queens have anteriorly yellowish abdominal tergum 2 and metanotum blackish.
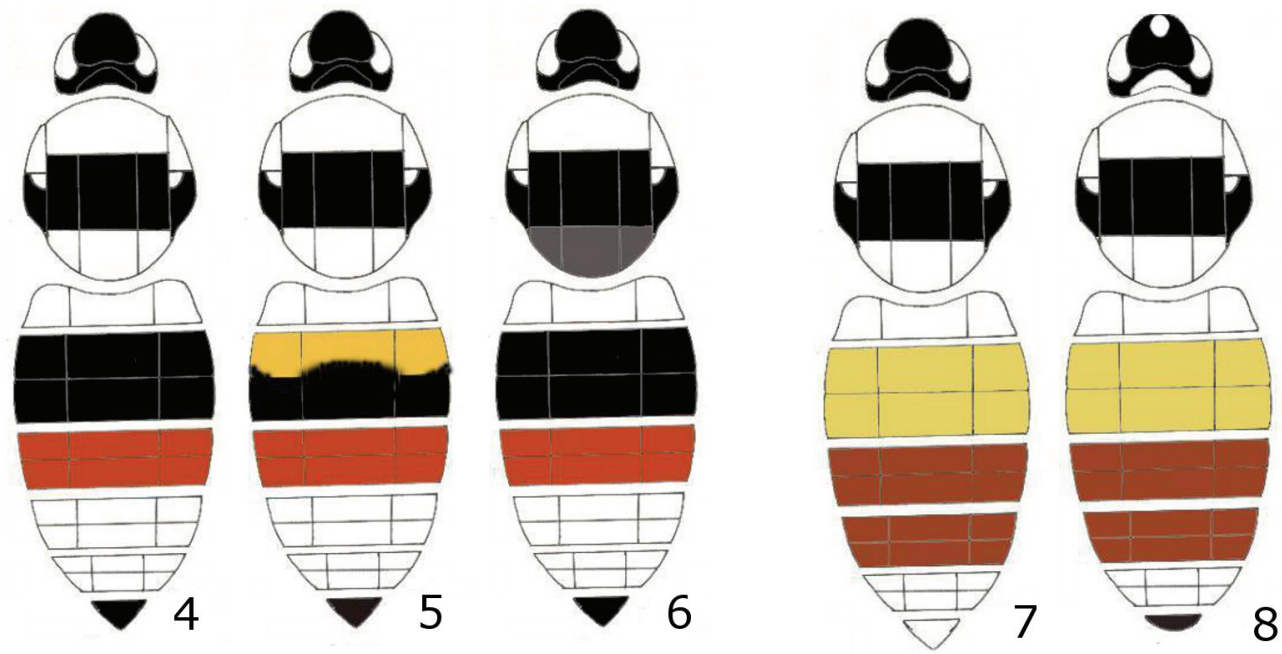

Figs 4-8. Colour pattern: 4-6 - queen, 7 - worker, 8 - male. 

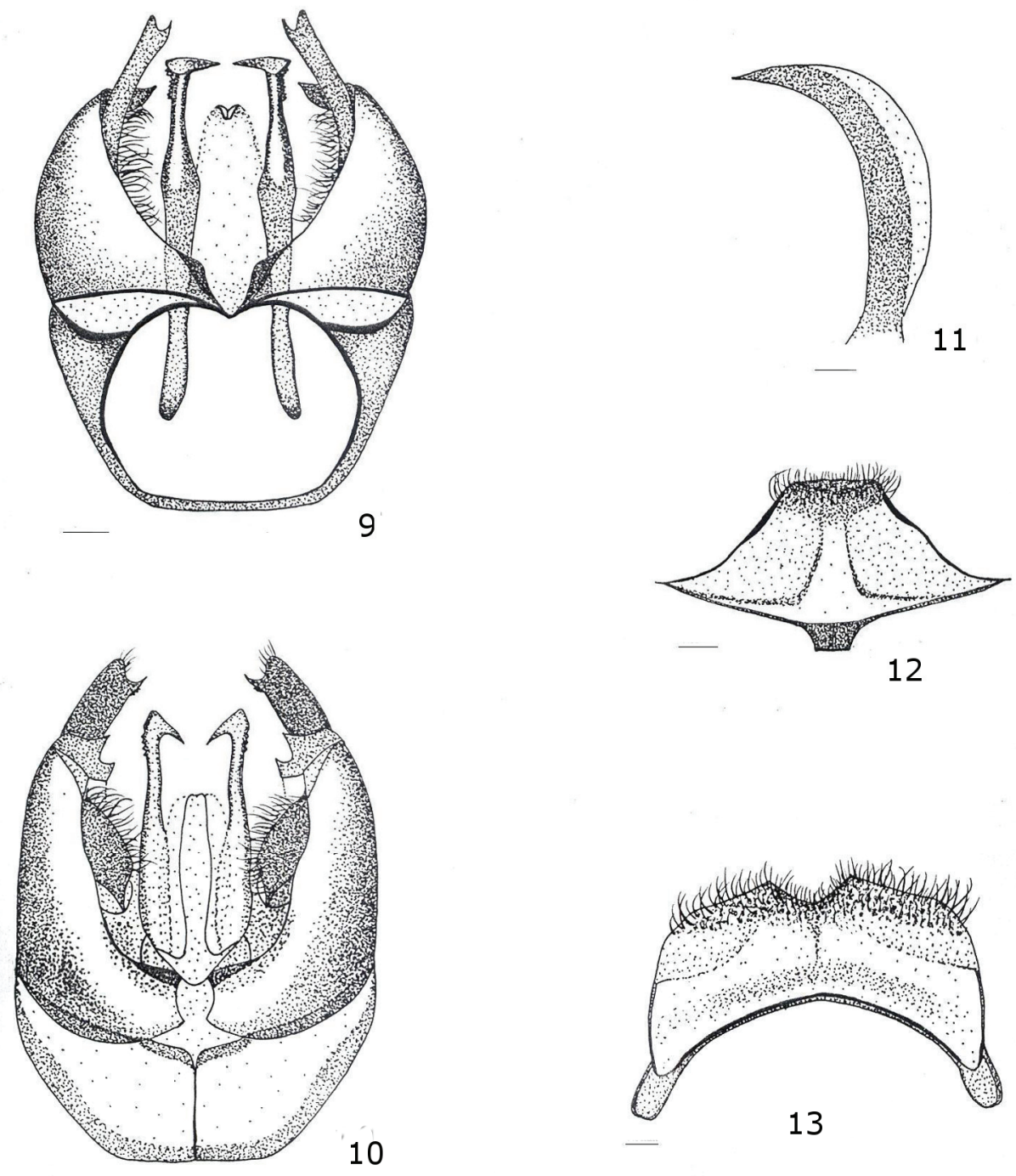

Figs 9-13. Male genitalia: 9 - ventral aspect, 10 - dorsal aspect, 11 - penis valve lateral view, $12-8^{\text {th }}$ sternite of male, $13-7^{\text {th }}$ sternite of male. Scale bar $=0.5 \mathrm{~mm}$.

\section{Food plants already recorded}

Cirsium falconeri (HoOK. F.), PetRAK; C. wallichii DC., Lactuca lessertiana (DC.) C.B. ClARKE (Asteraceae); Impatiens glandulifera ROYLE., (Balsaminaceae); L. quinquelocularis HARDW. (Caprifoliaceae); Rhododendron anthopogan D. DON. 
(Ericaceae); Swertia petiolata D. DON. (Gentianaceae); Nepeta podostachys BENTH., Phlomis bracteosa Royle ex Benth., Prunella vulgaris L., Thymus linearis Benth. ex BENTH. (Lamiaceae); Trifolium repens L., (Papilionaceae); Aconitum heterophyllum WALl., A. laeve RoYle, A. violaceum JACQ. ex STAPF. (Ranunculaceae); Digitalis lanata Ehrh., Pedicularis pectinata WAll. ex Benth, P. punctata DeCne, P. rhinanthoides SCHRENK ex FISCH., P. oederi VAHL., Scrophularia pauciflora BENTH. (Scrophulariaceae) (WILliAMS 1991).

Food plants recorded for the first time (Figs 23-27)

Allium sp. (Amaryllidaceae); Angelica glauca EDGEN. (Apiaceae); Antirrhinum majus L., Chrysanthemum sp., Cirsium arvense (L.) SCOP., Cirsium sp., Lactuca orientalis (DC.) C.B. Clarke, Ligularia sp., Saussurea albescens (DC.) SCH. BIP., S. auriculata (DC.) SCH. BIP., S. costus (FAlC.) Lipschitz., S. fastuosa (DECNE.) SCH. BIP., S. lappa C.B. ClARKE, Saussurea sp., Scorzonera virgata DC., Taraxacum officinale (Asteraceae); Impatiens sulcata WALL. (Balsaminaceae); Myosotis arvensis (L.) HILL. (Boraginaceae); Lonicera sp., (Caprifoliaceae); Sedum sp. (Crassulaceae); Dipsacus inermis WALl. (Dipsacaceae); Convolvulus arvensis L. (Convolvulaceae); Euphorbia wallichii HooK. F. (Euphorbiaceae); Gentiana cachemirica DECNE. (Gentianaceae); Geranium wallichianum D. DON (Geraniaceae); Iris hookeriana FOSTER, Iris sp. (Iridaceae); Ajuga sp., Euphrasia officinalis L., Marrubium vulgare L., (Lamiaceae); Trillium govanianum WALL. (Liliaceae); Hedysarum sp., Lupinus polyphyllus LindL., Oxytropis sp., Robinia pseudoacacia L., Trifolium pratense (Papilionaceae); Bistorta affins GREENE, B. vivipara (L.) GRAY. (Polygonaceae); Anagallis sp. (Primulaceae); Rosa webbiana WALL. (Rosaceae); Antirrhinum majus L., Lagotis cashmeriana (ROYLE) RUPR., Pedicularis roylei MAXIM., P. siphonantha D. DON, P. spicata PALl., P. verticillata L., Pedicularis spp. (Scrophulariaceae); Hyoscyamus niger L. (Solanaceae); Nardostachys chinensis BATAL (Valerianaceae).

\section{Altitude \\ 2400-4800 m above sea level. \\ Ecology}

Insect foraging behaviour is an area in which knowledge has advanced rapidly in recent years, and much of this research has focused on bumble bees. Bumble bees are excellent organisms for studying foraging behaviour. They are conspicuous, docile and easily observed without causing interference; and they forage ceaselessly, even under cool, cloudy conditions when other insects are inactive. Furthermore, studies of pollinator behaviour are of particular interest because the majority of flowering plants rely on insects to mediate pollen transfer. Thus, it is the behaviour of insects that determines which flowers will set seed and which will not. Bumble bees have become popular vehicles for examining the assumptions and predictions of foraging models and the interplay between learning, 
memory constraints and foraging efficiency in a complex and unpredictable environment. Foraging range is the fundamental aspect of bumble bee ecology, for it determines the area of the habitat that an individual or a colony can exploit, and understanding the spatial relationship between nest and food resources allows us to make predictions about colony survival and distribution (NAKAMURA \& TOQUENAGA 2002, Williams \& KREMEN 2007). During the present study B. rufofasciatus was selected to study foraging behaviour. 10 workers were marked on the thorax with different colours at their nest sites and released; later, a smaller number of the marked bees were re-sited at different distances from $200 \mathrm{~m}$ to $1500 \mathrm{~m}$. B. rufofasciatus regularly forages $<1500 \mathrm{~m}$ of its nests. A strong correlation between foraging range and colony size was observed during the current study. The largest colony of $B$. rufofasciatus contained 175 workers. It was found that the larger the colony size, the greater the foraging range. This obviously makes sense, as a large colony needs to range over a larger area to find sufficient food, all else being equal.

It was also observed that B. rufofasciatus forages heavily in the afternoon, with restricted activity in the early morning and late in the evening at high altitudes. Foraging activities were also recorded at 10:00, 14:00 and 18:00 hrs. The frequency of visits was also recorded - 6-8 per minute; this observation is in conformity with earlier studies (DARWIN 1876, Grant 1950, Free 1970a LeVIn \& ANDERSON 1970, HeNrich 1979, WASER 1986, LEWIS 1986, 1989). B. rufofasciatus was also observed to have a broad host spectrum. Though the bees have a long list of preferred flowers, it does not include many apparently suitable flowers types or species. Bumble bees mostly prefer members of Asteraceae, followed by Lamiaceae and Papilionaceae. 51 food plants of B. rufofasciatus have been recorded for the first time from the study area. All the food plants were identified by different persons (see Acknowledgements).

The overall picture reveals that there are some plants on which B. rufofasciatus feeds heavily, such as Cirsium arvensis, Cirsium falconeri, Carduus spp., Nepeta spp., Prunella vulgaris, Impatiens balsamina, Saussurea spp., Trifolium repens and Trifolium pratense. However, there are some other plants, like Artemisia spp., Pedicularis pectinata, Swertia spp. and Indigofera spp., which, though they occur in close proximity to the abovementioned plants, are seldom visited. The preference of bumble bees for particular host plants cannot be attributed to a single factor; rather a group of factors are involved. Some of them include the shape, size and colour of the flowers, the pollen content and pollen amount, season and situation, etc. The bumble bees were found to prefer flowers growing on open mountain slopes rather than in dense, closed-canopied forests. The shape of the flower is an important factor in this respect, bilaterally symmetrical flowers being preferred to asymmetrical and radially symmetrical ones, a fact that tallies with earlier studies (MOLler 1995, Moller \& SORCI 1998, WeST \& LAVERTY 1998). The bright pink flowers of Impatiens sulcata WALL. (Balsaminaceae) were preferred to the yellow flowers of 
Impatiens scabrida LINN. (Balsaminaceae), even when both these plant species were growing side by side.
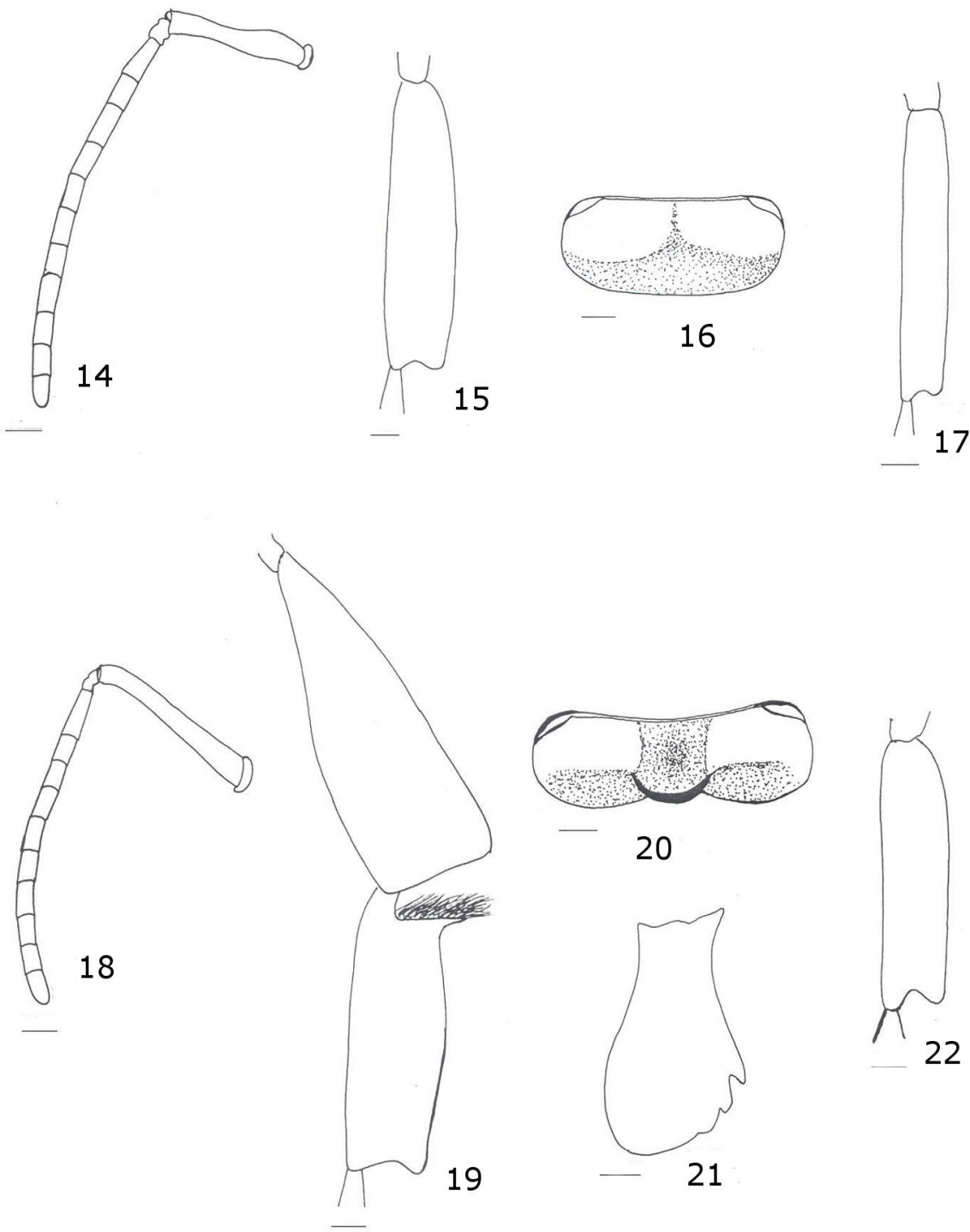

Figs 14-22. 14 - female antenna, 15 - female hind basitarsus, 16 - female labrum, 17 - female mid basitarsus, 18 - male antenna, 19 - male hind basitarsus, 20 - male labrum, 21 - male mandible, 22 male mid basitarsus. Scale bar $=0.5 \mathrm{~mm}$. 


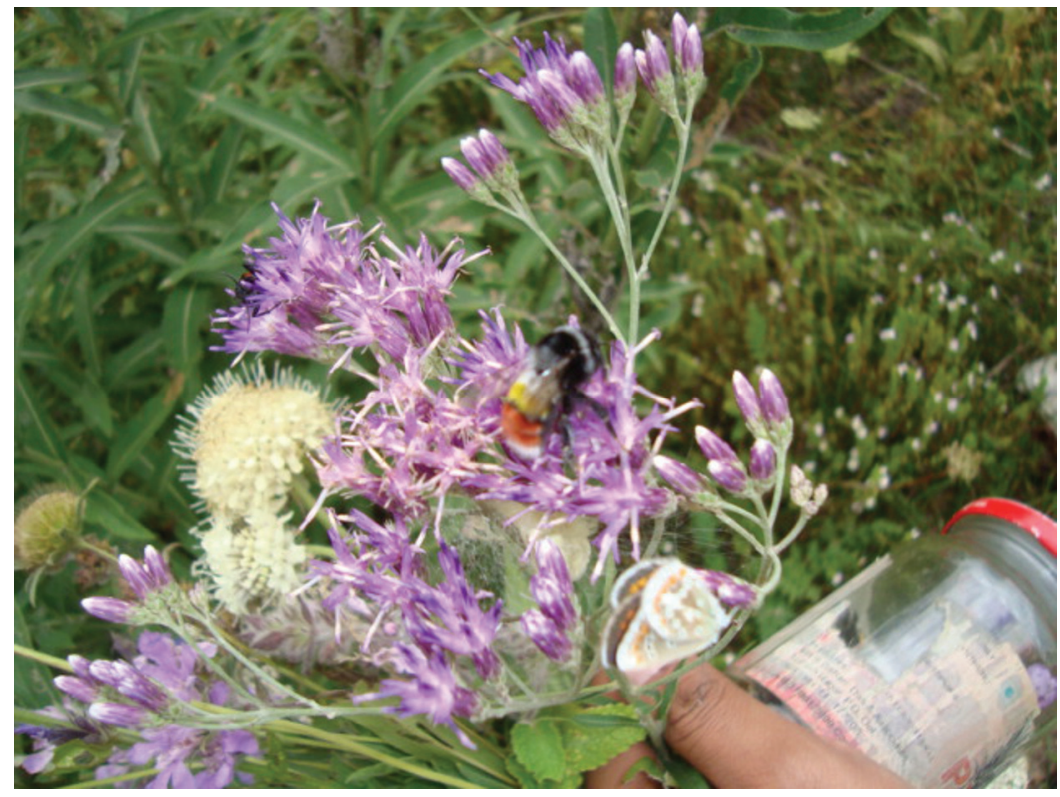

Fig. 23. B. rufofasciatus (male) on Cirsium arvensis.

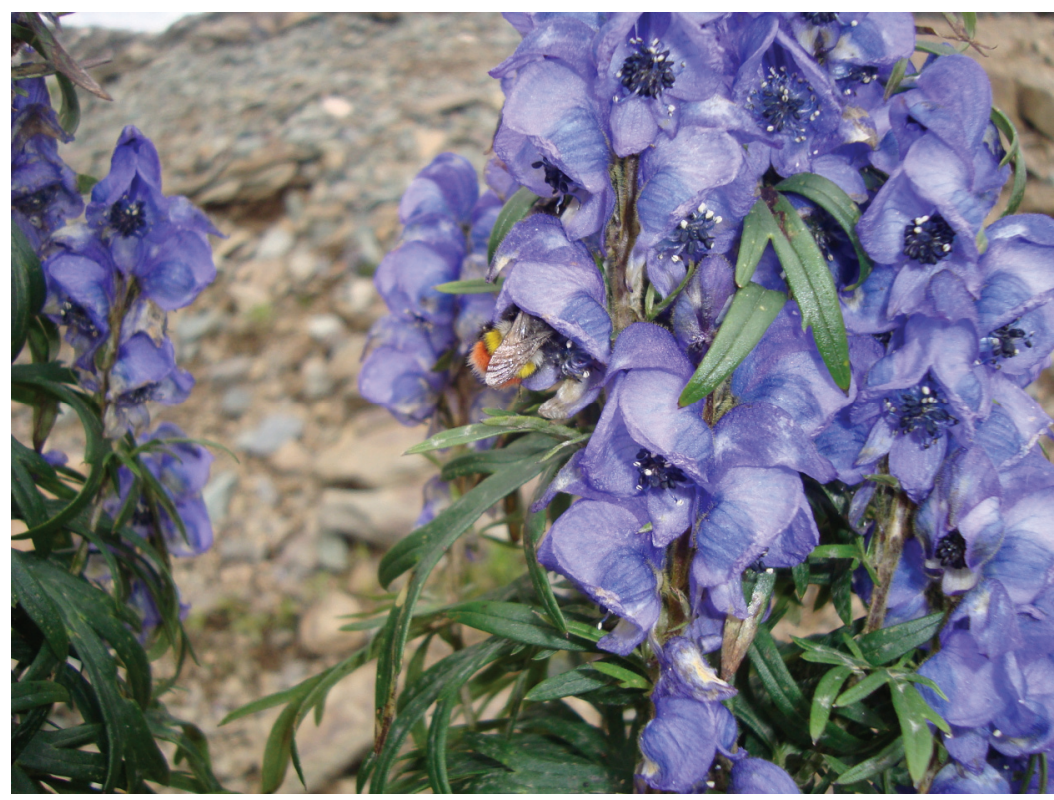

Fig. 24. B. rufofasciatus (worker) on Delphinium roylei. 


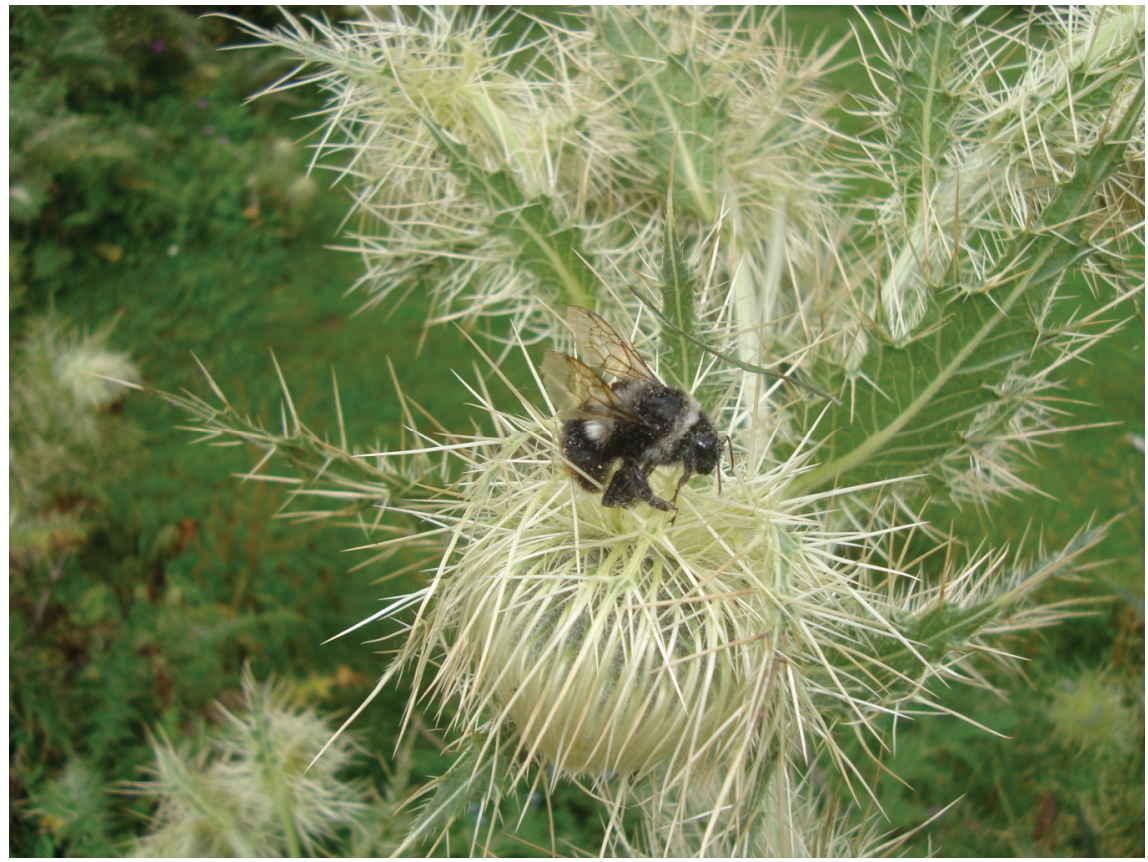

Fig. 25. B. rufofasciatus (queen) on Carduus edelbergii.

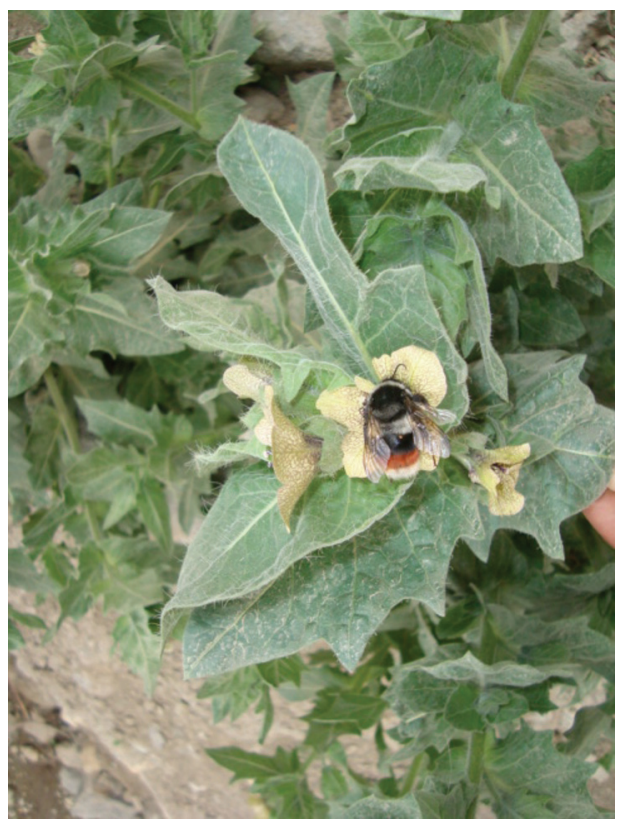

Fig. 26. B. rufofasciatus (queen) on Hyoscum niger. 


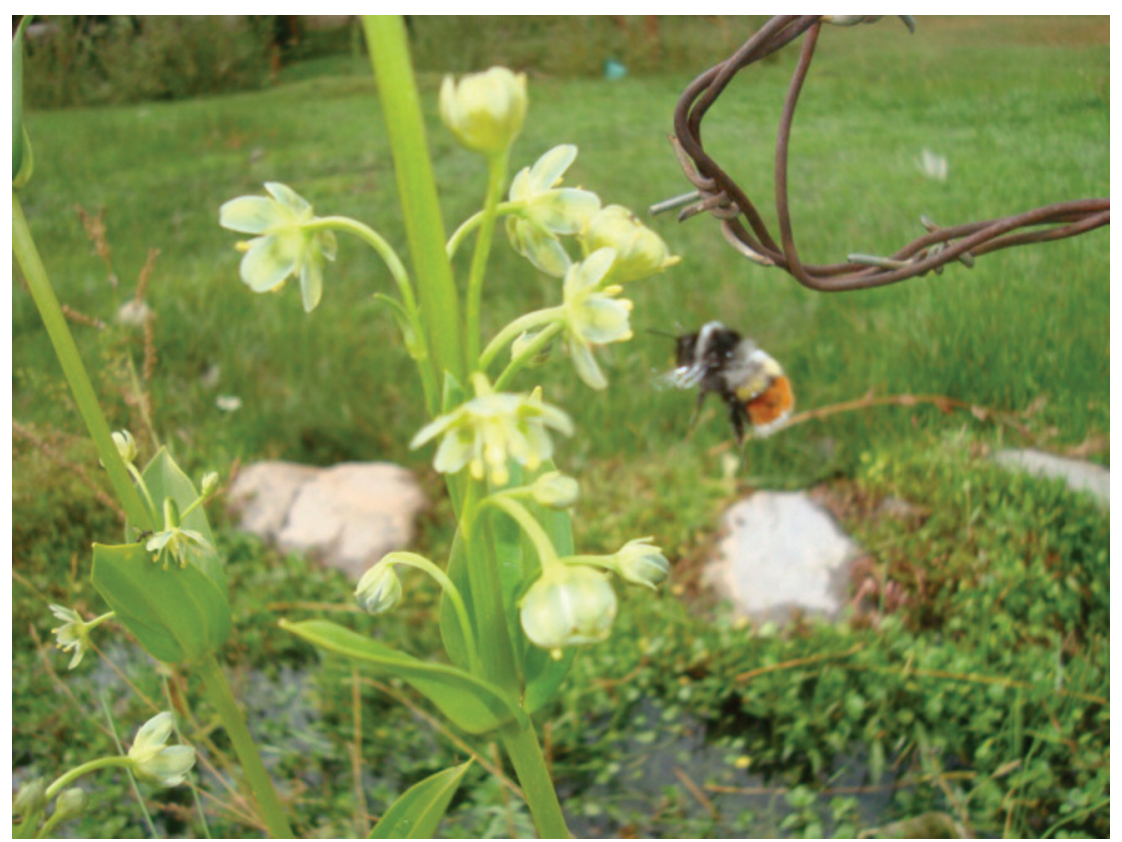

Fig. 27. B. rufofasciatus (worker) on Swertia sp.

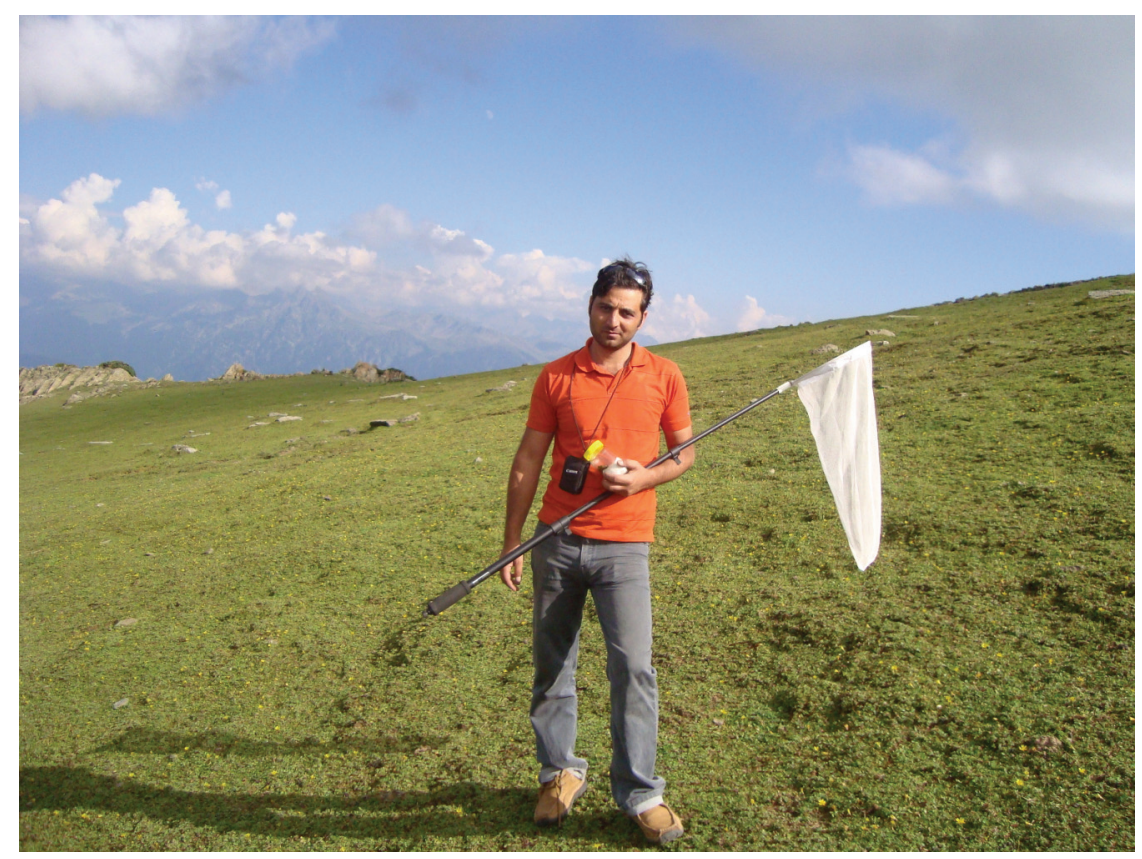

Fig. 28. Collection site at Razdhan Pass, 3500 m. 


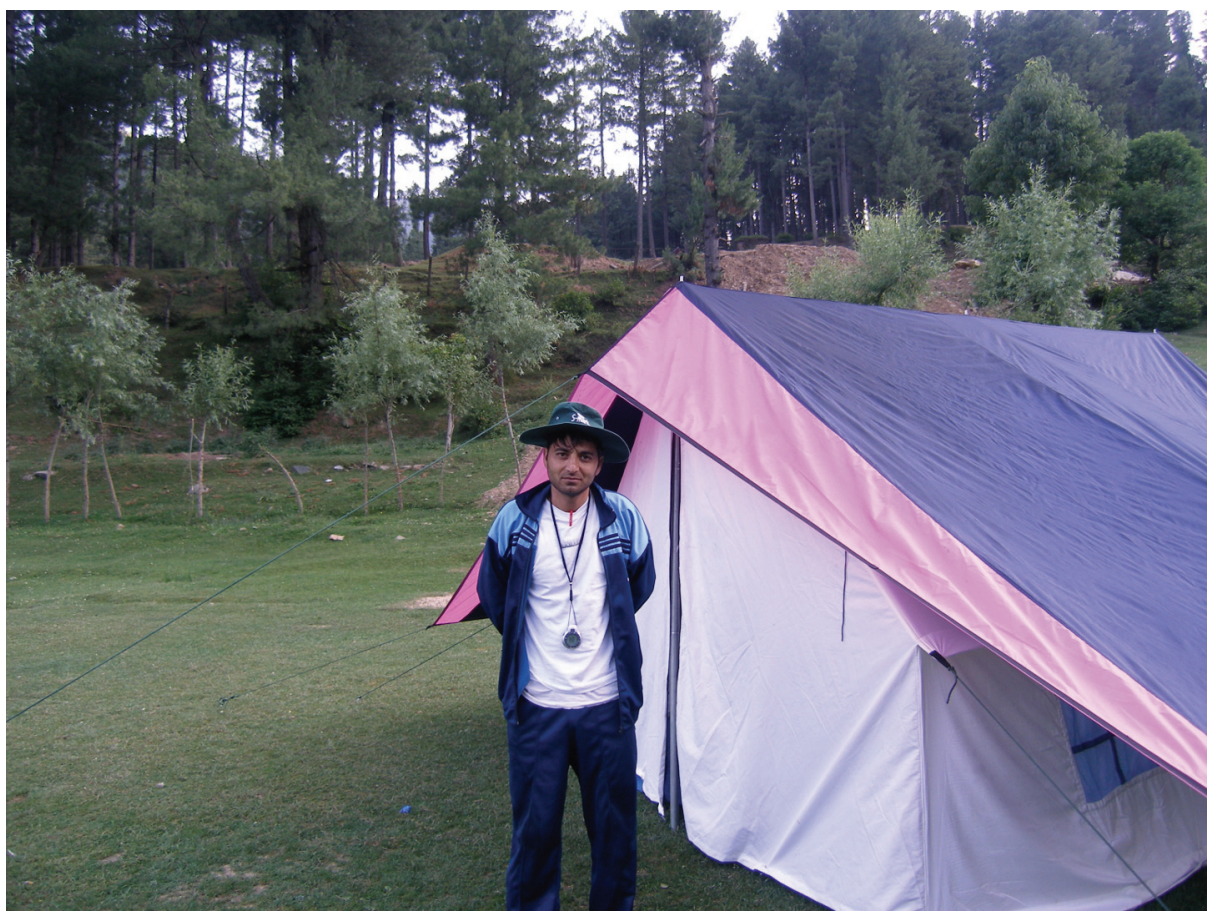

Fig. 29. Collection site at Daksum, $3000 \mathrm{~m}$.

\section{REFERENCES}

BINGHAm C.T. 1897. The fauna of British India, including Ceylon and Burma. Hymenoptera. Vol. 1. Wasps and bees. London, Taylor and Francis.

Burger F., Creutzburg F., Hartmann J., Hartmann M. 2009. Biodiversität und Naturausstattung im Himalaya III. [In:] HARTMANN M. und WeIPERT J. (eds). Erfurt. Verein der Freunde und Förderer des Naturkundemuseums, Erfurt.

DAlla TORRE K.W. VON 1890. Hymenopterologische Notizen. Wiener Entomologische Zeitung 9: 139.

DAlla TORRE K.W. VON 1896. Catalogus hymenopterorum hucusque descriptorum systematicus et synonymicus. Volumen X: Apidae (Anthophila). Lipsiae: Sumptibus Gulilmi Englemann.

DARWIN C. 1859. On the origin of species by means of natural selection, or the preservation of favoured races in the struggle for life. London, John Murray.

DRAMSTAD W.E. 1996. Do bumblebees (Hymenoptera: Apidae) really forage close to their nests? Journal of Insect Behaviour 2: 163-182.

FreE J.B. 1970. Insect pollination of crops. London, Academic Press Inc. (London) Ltd.

GRANT V. 1950. The flower constancy of bees. Botanical Review 3: 82-97.

HEINRICH B. 1979. Bumblebee economics. Massachusetts, Harvard University Press.

International Commission on Zoological Nomenclature (1999). International code of zoological nomenclature 4: 1-303. 
KeARnS C.A., Thomson J.D. 2001. The natural history of bumblebees: a source book for investigation. First edition. Boulder, University Press of Colorado.

KEVAN P.G. 1976. Fluorescent nectar (technical comment). Science 194: 341-342.

LEVIN D., ANDERSON W.W. 1970 Competition for pollinators between simultaneously flowering species. American Naturalist 104: 455-467.

LEWIS A.C. 1986. Memory constraints and flower choice in Pieris rapae. Science 232: 863-865.

LEWIS A.C. 1989. Flower visit consistency in Pieris rapae, the cabbage butterfly. Journal of Animal Ecology 58: 1-13.

Molier A.P. 1995. Bumble bee preference for symmetrical flowers. Proceedings of National Academy of Sciences USA 92: 2288-2292.

MOLIER A.P., SORCi G. 1998. Insect preference for symmetrical artificial flowers. Oecologia 114: 37-42.

MorawitZ F. 1880. Ein Beitrag zur Bienen-Fauna Mittel-Asiens. Izvestiya Imperatorskoi Akademii Nauk 26: 337-379.

MorawiTz F. 1890. Insecta a Cl. G. N. Potanin in China et in Mongolia novissime lecta. XIV. Hymenoptera Aculeata. II). III. Apidae. Trudy Russkago éntomologicheskago obshchestva 24: 349-385.

NAKAmura H., Toquenaga Y. 2002. Estimating colony locations of bumble bees with the moving average model. Economic Research 17: 39-48.

Osborne J. L., Clark S.J., Morris R.J., Williams I.H., Riley J.R., Smith A.D., Reynolds D.R., EDWARDS A.S. 1999. A landscape scale study of bumble bee foraging range and constancy, using harmonic radar. Journal of Applied Ecology 36: 519-533.

RichARDS O.W. 1928a. Bombus volucella in the Himalayas. Entomological Monthly Magazine 64: 107-108.

RichARDS O.W. 1928b. On a collection of bumble-bees (Hymenoptera, Bombidae) made in Ladakh by Col. R. Meinertzhagen. Annals and Magazine of Natural History 2: 333-336.

RichARDS O.W. 1930. The bumble bees captured on the expeditions to Mt. Everest (Hymenoptera, Bombidae). Annals and Magazine of Natural History 5: 633-658.

RiCHARDS O.W. 1934. Some new species and varieties of oriental bumble bees (Hym., Bombidae). Stylops 3: 87-90.

SAINI M.S, RAINA R.H., KHAN Z.H. 2011. A check list of bumblebees (Hymenoptera: Apidae) from the Indian Himalaya. Journal of Insect Science 24: 326-352.

SAINI M.S, RAINA R.H., KHAN Z.H. 2011. Species diversity of bumblebees (Hymenoptera: Apidae) from different mountain regions of Kashmir Himalayas. Journal of Scientific Research 4: 263-272.

SKoriKov A.S. 1923. Palaearctic bumblebees. Part I. General biology (including zoogeography). Izvestiya Severnoi Oblastnoi Stantsii Zashchity Rastenii ot Vreditelei 4: 1-160.

SMITH F. 1852. Descriptions of some hymenopterous insects from northern India. Transactions of the Entomological Society of London 2: 45-48.

TKALCU B. 1974. Eine Hummel-Ausbeute aus dem Nepal-Himalaya (Insecta, Hymenoptera, Apoidea, Bombinae). Senckenbergiana Biologica 55: 311-349.

WANG S. 1982. Insects of Xizang. Beijing, Geological Publishing House.

WANG S. 1988. Insects of Mt. Namjagbarwa region of Xizang. HuANG F. (ed.). Beijing, Science Press, Beijing, 553 pp.

WASER N.M. 1986. Flower constancy: definition, cause and measurement. American Naturalist 127: 593-603.

WEST E.L., LAVERTY T.M. 1998. Effect of floral symmetry on flower choice and foraging behaviour of bumble bees. Canadian Journal of Zoology 76: 730-739.

Westrich P. 1996. The conservation of bees. [In:] Matheson A., Buchmann S., Toole C.O., Westrich P., Williams I.H. (eds). London, Academic Press London. 
Williams N. M., KREMEN C. 2007. Resource distributions among habitats determine solitary bee offspring production in a mosaic landscape. Economic Applications 17: 910-921.

Williams P.H. 1991. The bumble bees of the Kashmir Himalaya (Hymenoptera: Apidea; Bombinae). Bulletin of Natural History Museum London (Entomology) 60: 1-204.

Williams P.H., CAmeron S.A. 1993. Bumble bee (Bombus LATR.) records from the valley of flowers. Uttar Pradesh Bulletin of Entomology 31: 125-127.

Received: June 11, 2012

Accepted: August 22, 2012 